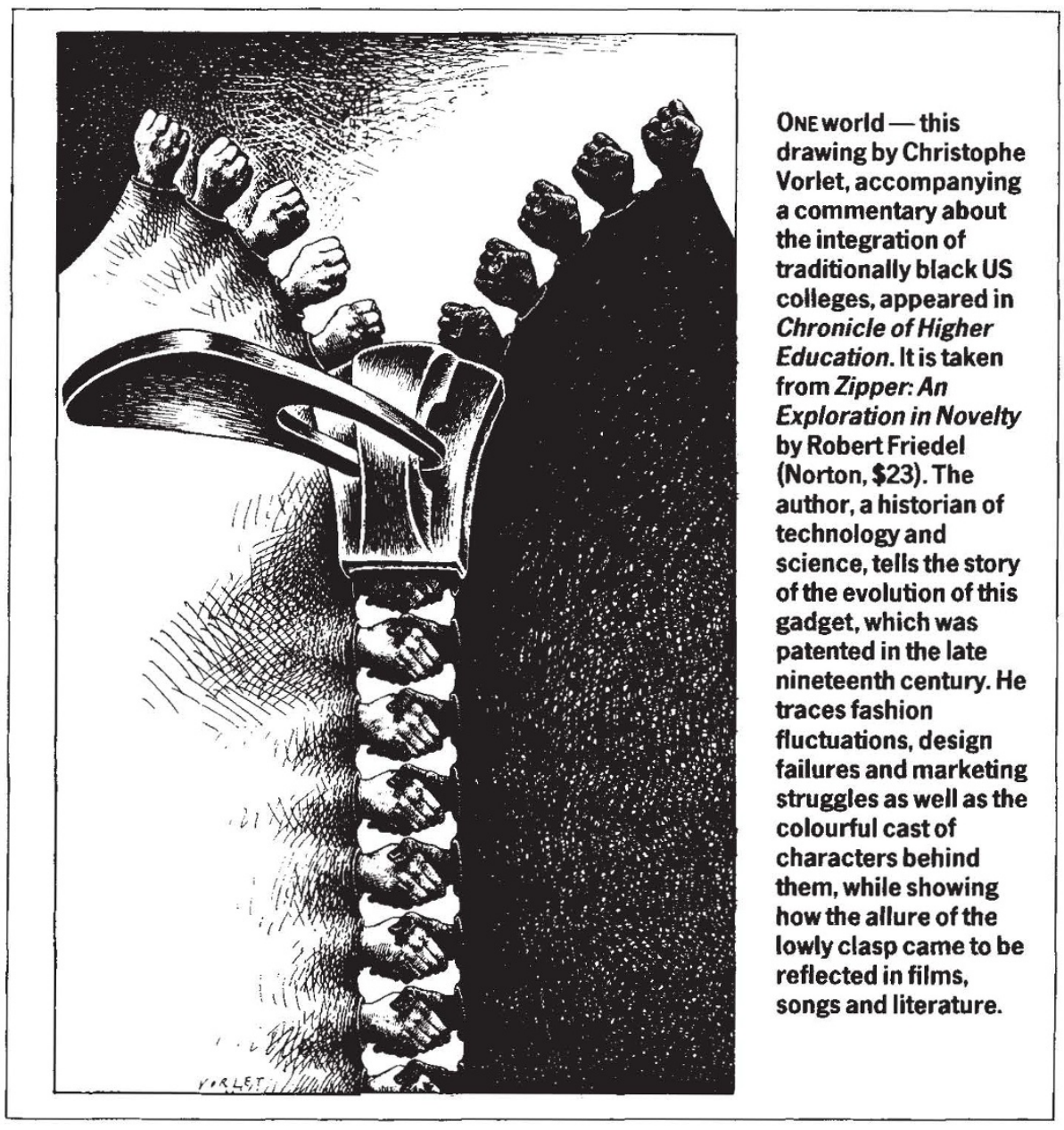

\section{Angel in America}

Richard Davenport-Hines

My Own Country: A Doctor's Story of a Town and Its People in the Age of AIDS. By Abraham Verghese. Simon and Schuster: 1994. Pp. 347. \$23*.

SINCE the identification of AIDS in the 1980 s, there has been a plethora of general books by people touched by the syndrome. Many of these have been by patients or their survivors, but My Own Country is the first written by a physician about his patients in the Bible Belt of the United States. As a piece of medical literature intended for general readers, it bears comparison with the essays of Sir Frederick Treves or Sir William Osler.

In 1985, Abraham Verghese was a young doctor specializing in infectious disease and living in Johnson City, Tennessee. His book opens with a description of the first patient with AIDS in the city: a young man returning from New York to visit his parents, who dies of pneumocystis carinii, and whose illness causes such panic among the hospital authorities that, after his death, it was proposed to bury the

*Soundings in the UK (Phoenix House, f18.99) social justice and sexual conduct, and sometimes gives his own answers, in a tone that is never peremptory or arrogant but has a gentle persistent subversiveness.

The AIDS patients whose cases he describes include gay men, intravenous drug users, haemophiliacs, the wife of a bisexual, a businessman infected by blood transfusion, and the wife whom the latter too has infected. He writes of them with a vividness that is an act of commemoration; he is never mawkish and keeps a measure of dignity even for patients far gone in dementia. His grief over the plight of some patients, his alertness to human nuances, his curiosity and capacity for surprising himself are all powerfully conveyed, although this is the least egocentric of books.

One of its strongest features is Verghese's gradually developing understanding of the diversities of human sexual behaviour. One women nursing her brother says of him to Verghese, "Gay may have been what he did, but it wasn't who he was", and this remark might serve as an epigraph for his book. Any physician interested in the realities of Western sexual behaviour, rather than the sterile statistics of sexologists or the stereotyped polemics of militants, will find Verghese's ideas fascinating. He comes to suspect that gay men "are more representative of men than heterosexual men" because "the sexual activity of gay men, their sexual drive, the number and variety of partners, the ready possibility of anonymous sex, might represent what all men want, except that they can't get women to agree". Not surprisingly the strain that his new medical interest places on his marriage provides an ominous personal note.

My Own Country is outstanding. It is elegantly written, with descriptions of Tennessee landscape worthy of a Pulitzer prizewinner. It has grace, moral power and a strong social commentary. The lives of the Tennessee people seem dominated by technology - one dying man keeps the police radio monitor blaring all day in his bedroom - yet they remain as simple and even superstitious in their concerns as mediaeval serfs, although a patina of education conceals this from themselves and others. Verghese deals at times with highly emotive topics, and describes some deeply emotional scenes of life and death, but his literary treatment is pitched at just the right level of mild understatement. This is a modest, humane, reflective book, full of images and ideas that resonate and enrich. Every reader will be provoked to rethink old assumptions by this gently challenging and finely observed book. Every patient faced with serious illness will hope to have a physician like Verghese.

Richard Davenport-Hines is at 51 Elsham Road, London W14'8HD, UK. 